\title{
EVALUATION OF SUNFLOWER HYBRIDS FOR YIELD VARIABILITY AT VERY HIGH AIR TEMPERATURES
}

${ }^{1}$ Makliak K.M., ${ }^{1}$ Kyrychenko V.V., ${ }^{2}$ Varenyk B.F., ${ }^{3}$ Kutishcheva N.M., ${ }^{4}$ Trotsenko V.I.

1 - Plant Production Institute named after V.Ya. Yuriev of NAAS, Ukraine;

${ }^{2}$ - Plant Breeding and Genetic Institute - National Center of Seed and Cultivar Investigation, Ukraine;

3 - Institute of Oil Crops of NAAS, Ukraine;

${ }^{4}$ - Institute of Agriculture of the North-East of NAAS, Ukraine

The results of evaluation of hybrids sunflower for yield variability at very high air temperatures in the moderately arid agroclimatic zone of Ukraine are presented. In 2007-2008 and 2014-2015, 99 simple and three-line hybrid combinations based on lines-parents bred in the Plant Production Institute named after V.Ya. Yuriev of NAAS, Institute of Oil Crops of NAAS and Plant Breeding and Genetic Institute - National Center of Seed and Cultivar Investigation were tested. The "heat resistance index" of the genotype was proposed; the best hybrid combinations, which maintain high performance at very high air temperatures, were selected.

Key words: sunflower, trials, adaptability, general, specific, index, heat resistance

Introduction. Major factors limiting the sunflower production in the moderately arid agro-climatic zone of Ukraine include very high (above $30^{\circ} \mathrm{C}$ ) air temperatures called as "heat" [1]. The number of days in July-August, when the temperature is very high, in the southern and eastern regions is $20-40 \%$ of the total number of days per month [2]. Such extended action of very high temperatures (thermal stress) significantly reduces yields in comparison with the full genetic potential of the genotype [3]. Solving methodological issues of assessment of yield variability in the conditions of heat is of particular importance.

Analysis of literature, problem statement. Researchers from different countries reported about the significant influence of temperature regime during the growing season on the economic characteristics of sunflower (yield, oil content in seeds, oil output) and the genetically determined characteristics of the response of breeding material to air temperature $[4,5,6]$. Susceptible sunflower genotypes lose up to one third of their yields, when the maximum air temperature rises by $2^{\circ} \mathrm{C}$ above the optimum [7]. The main purpose of sunflower breeding for resistance to very high temperatures is to minimize yield losses, and high yields under such conditions are an indisputable criterion for selecting genotypes [8].

The development of techniques for distinguishing the effect of air temperature on yields in the field from the influence of other environmental factors involves creation of a maximum contrast stress load on the genotype, which can be provided by variety trials under various climatic conditions (environmental variety trials). Evaluation of sunflower genotypes in variety trials in different agro-soil zones of Ukraine allowed establishing the performance potential of hybrid combinations, levels of their general and specific adaptability, parameters of test environments as background for yield assessment $[9,10,11]$.

HI Oka defined the general adaptive capacity of an agricultural crop as the ability to give a stable yield under various growing conditions and the specific adaptive capacity - as the ability to respond and to be stable under specific conditions (cold, heat, drought, disease, pests) [12]. In the latter case, specific factors of the environment that determine the crop yield variability and the peculiarities of their influence (ontogenetic phase, manifestation level of a factor ensuring the maximum differentiation of a population) must be known. For example, the sunflower yield is greatly affected by very high temperatures in July, during the sunflower anthesis and onset of seed filling. Temperatures above $31^{\circ} \mathrm{C}$ during anthesis reduce the pollen production and flower

(c) K.M. Makliak, V.V. Kyrychenko, B.F. Varenyk, N.M. Kutishcheva, V.I. Trotsenko. 2018. ISSN 1026-9959. Селекція і насінництво. 2018. Випуск 114. 
fertility, leading to pollen sterilization, "burnout" of stigmas and reduction in the amount of seeds, sometimes to zero $[13,14]$. Temperatures above $27^{\circ} \mathrm{C}$ during the filling period (August) significantly reduces the ultimate weight of achenes [15]. Evaluation of genotypes on a provocative background, where the factor limiting yields in the region (in particular, very high temperatures) acts, will allow detecting resistant accessions [16].

Here, the methodical issue of choosing a statistical parameter for selection of accessions that can maintain stable yields under certain environmental conditions or reduce them less than other genotypes arises.

Purpose and objective. The purpose of the study was to develop methodological approaches to quantification of the yield variability of sunflower hybrids at very high air temperatures (heat).

Materials and methods. The field experiments were carried out in the scientific crop rotation fields of the Plant Production Institute named after V.Ya. Yuriev of NAAS (hereinafter referred to as PPI nd. a V.Ya. Yuriev), Kharkiv, Institute of Oil Crops of NAAS (hereinafter referred to as IOC), Zaporizhzhia and in the fields of the experimental base "Dacha" of the Plant Breeding and Genetic Institute - National Center of Seed and Cultivar Investigation (hereinafter referred to as PBGI-NCSCI), Odessa, in 2007-2008 and 2014-2015; in the scientific crop rotation fields of Luhansk Institute of Agricultural Production of UAAS (hereinafter referred to as LIAP), Luhansk, in 2014-2015; in the scientific crop rotation fields of the Institute of Agriculture of the North East of NAAS (hereinafter referred to as IANE), Sumy, in 2007-2008.

In the text, the following symbols are used: Khi - trials of genotypes were conducted in the PPI nd. a V.Ya. Yuriev in the $i^{\text {th }}$ year; $\mathrm{Zi}$ - trials of genotypes were conducted in the IOC in the $i^{\text {th }}$ year; Oi - trials of genotypes were conducted in the PBGI-NCSCI in the $i^{\text {th }}$ year; Li - trials of genotypes were conducted in LIAP in the $i^{\text {th }}$ year; $\mathrm{Si}$ - trials of genotypes were conducted in the IANE in the $i^{\text {th }}$ year.

According to agroclimatic zoning, the lands used by the research institutions are located in the moderately arid zone and the insufficiently humidified zone [17]. The PPI's land is located in the moderately arid agro-climatic zone; the agro-soil zone is the forest-steppe of the Left-Bank high southeast agro-soil province with typical black earths. The IOC's lands are located in the moderately arid zone; the agro-soil subzone is the northern steppe of the northern steppe RightBank agro-soil province with typical black earths. The lands of the experimental base "Dachna" of the PBGI-NCSCI are located in the moderately arid zone; the agro-soil subzone is the southern steppe of the southern-steppe Right-Bank agro-soil province with southern black earths. The LIAP's lands are is located in the moderately arid zone; the agro-soil subzone is the northern steppe of Donetsk agro-soil province with common black earths. The IANE's lands are located in the insufficiently humidified agro-climatic zone; the agro-soil zone is the forest-steppe of the north-eastern high agro-soil province with typical black earths.

The sum of active temperatures (above $+10^{\circ} \mathrm{C}$ ) varies from $3200-3400^{\circ} \mathrm{C}$ (PBGI-NCSCI) to $2400^{\circ} \mathrm{C}$ (IANE). The average annual precipitation varies from $350-390 \mathrm{~mm}$ (PBGI-NCSCI) to $590 \mathrm{~mm}$ (IANE).

The weather conditions during the sunflower growing season (May-August) significantly differed over the study years and sites.

In Kharkiv (data of the weather station "Airport", $49^{\circ} 55^{\prime} \mathrm{N}, 36^{\circ} 17^{\prime} \mathrm{E}$ ), the average daily temperature in May-August was $21.1^{\circ} \mathrm{C}$ in $2007,19.1^{\circ} \mathrm{C}$ in $2008,20.5^{\circ} \mathrm{C}$ in 2014 , and $20.1^{\circ} \mathrm{C}$ in 2015 (the norm of $1981-2010=19.1^{\circ} \mathrm{C}$ ). The amount of precipitation during this period was $251.7 \mathrm{~mm}$ in 2007, $201.0 \mathrm{~mm}$ in $2008,217.7 \mathrm{~mm}$ in 2014 , and $253.7 \mathrm{~mm}$ in 2015 (the norm = $215.0 \mathrm{~mm})$.

In Zaporizhzhia (data of the IOC weather station, $47^{\circ} 51^{\prime} \mathrm{N}, 35^{\circ} 9^{\prime} \mathrm{E}$ ), the average daily temperature in May-August was $25.3^{\circ} \mathrm{C}$ in $2007,23.2^{\circ} \mathrm{C}$ in $2008,24.0^{\circ} \mathrm{C}$ in 2014 , and $24.4^{\circ} \mathrm{C}$ in 2015 (the norm of $1961-1990=20.4^{\circ} \mathrm{C}$ ). The precipitation amount was $105 \mathrm{~mm}$ in $2007,149.8$ $\mathrm{mm}$ in 2008, $156.5 \mathrm{~mm}$ in 2014, and $264.0 \mathrm{~mm}$ in 2015 (the norm $=184.0 \mathrm{~mm}$ ).

In Odessa (data of the Hydrometeorological Center of the Black and Azov Seas, $46^{\circ} 26^{\prime} \mathrm{N}$, $30^{\circ} 46^{\prime} \mathrm{E}$ ), the average daily air temperature in May-August was $22.6^{\circ} \mathrm{C}$ in $2007,20.7^{\circ} \mathrm{C}$ in 2008 , 
$21.5^{\circ} \mathrm{C}$ in 2014 , and $21.3^{\circ} \mathrm{C}$ in 2015 (the norm of $1961-1990=19.3^{\circ} \mathrm{C}$ ). The precipitation amount was $93.8 \mathrm{~mm}$ in 2007, $161.5 \mathrm{~mm}$ in 2008, $166.4 \mathrm{~mm}$ in 2014, and $141.2 \mathrm{~mm}$ in 2015 (the norm = $164 \mathrm{~mm})$.

In Luhansk (data of Luhansk Regional Hydrometeorological Center, 48 $333^{\prime} \mathrm{N}, 39^{\circ} 19^{\prime} \mathrm{E}$ ), the average daily air temperature in May-August was $22.3^{\circ} \mathrm{C}$ in 2007 and $20.0^{\circ} \mathrm{C}$ in 2008 (the norm of $1961-1990=20.0^{\circ} \mathrm{C}$ ). The precipitation amount was $56.6 \mathrm{~mm}$ in 2007 and $163.8 \mathrm{~mm}$ in 2008 (the norm $=201 \mathrm{~mm}$ ).

In Sumy (data of the IANE meteorological station, $50^{\circ} 88^{\prime} \mathrm{N}, 34^{\circ} 71^{\prime} \mathrm{E}$ ), the average daily air temperature in May-August was $21.1^{\circ} \mathrm{C}$ in 2014 and $20.3^{\circ} \mathrm{C}$ in 2015 (the norm of $1961-1990$ $=18.5^{\circ} \mathrm{C}$ ). The precipitation amount was $245.8 \mathrm{~mm}$ in 2014 and $278.1 \mathrm{~mm}$ in 2015 (the norm $=$ $254.0 \mathrm{~mm})$.

Thus, the soil and weather-climatic conditions in the study years and sites significantly differed and allowed full covering the range of agroclimatic conditions of the potential dissemination acreage of sunflower hybrids.

The data on the average maximum temperature $\left(t_{\max }\right)$ in July and the first 10 days of August were used to determine differences between the temperature regimens of the study years and sites and to select the environment with the maximum stress load.

In environment $\mathrm{Z}_{07}$, the $\mathrm{t}_{\max }$ in July $\left(34.3^{\circ} \mathrm{C}\right)$ was significantly (by $4.8^{\circ} \mathrm{C}$ ) higher than the average $t_{\max }\left(29.5^{\circ} \mathrm{C}\right)$ (Table 1). The average yield of hybrids in $Z_{07}$ was $2.51 \mathrm{t} /$ ha and did not differ significantly from the average yield across the variants $(2.49 \mathrm{t} / \mathrm{ha})$.

Table 1

Average maximum temperature $\left(t_{\max }\right)$ in July and the yield of $F_{1}$ sunflower hybrids, 2007-2008

\begin{tabular}{cccccccccc}
\hline Parameter & $\mathrm{Kh}_{07}$ & $\mathrm{Kh}_{08}$ & $\mathbf{Z}_{07}$ & $\mathrm{Z}_{08}$ & $\mathrm{~L}_{07}$ & $\mathrm{~L}_{08}$ & $\mathrm{O}_{07}$ & $\mathrm{O}_{08}$ & Average \\
\hline $\mathrm{t}_{\max }$ in July, ${ }^{\circ} \mathrm{C}$ & 27.3 & 27.2 & $\mathbf{3 4 . 3 ^ { * }}$ & 28.8 & 31.2 & 30.1 & 29.7 & 27.0 & 29.5 \\
Yield, t/ha & $3.81^{*}$ & $3.56^{*}$ & $\mathbf{2 . 5 1}$ & 2.20 & $2.02^{*}$ & $1.78^{*}$ & $1.37^{*}$ & $2.67^{*}$ & 2.49 \\
\hline
\end{tabular}

Footnote 1. " - significantly different from the total average across the variants

Footnote 2. $\mathrm{LSD}_{05}$ of pair comparison between the yields: $0.40 \mathrm{t} / \mathrm{ha}$

In environment $\mathrm{Z}_{14}$, the $\mathrm{t}_{\max }$ in August $\left(34.6^{\circ} \mathrm{C}\right.$ ) significantly (by $3.4^{\circ} \mathrm{C}$ ) exceeded the average $\mathrm{t}_{\max }$ across the variants $\left(31.2^{\circ} \mathrm{C}\right)$ (Table 2$)$. The average yield of hybrids in $\mathrm{Z}_{14}$ amounted to $1.96 \mathrm{t} / \mathrm{ha}$ and was significantly lower (by $0.83 \mathrm{t} / \mathrm{ha}$ ) than the average yield across the variants (2.79 t/ha).

Table 2

Average maximum temperature ( $t_{\max }$ ) for the first 10 days of August and the yield of $F_{1}$ sunflower hybrids, 2014-2015

\begin{tabular}{cccccccccc}
\hline Parameter & $\mathrm{Kh}_{14}$ & $\mathrm{Kh}_{15}$ & $\mathbf{Z}_{14}$ & $\mathrm{Z}_{15}$ & $\mathrm{O}_{14}$ & $\mathrm{O}_{15}$ & $\mathrm{~S}_{14}$ & $\mathrm{~S}_{15}$ & Average \\
\hline $\begin{array}{c}\mathrm{t}_{\max } \text { for the first 10 } \\
\text { days of August, }{ }^{\circ} \mathrm{C}\end{array}$ & 31,7 & 28,7 & $\mathbf{3 4 , 6}^{*}$ & 32,0 & 32,2 & 30,7 & 31,1 & 28,4 & 31,2 \\
Yield, t/ha & $3,76^{*}$ & $3,31^{*}$ & $\mathbf{1 , 9 6}^{*}$ & $3,22^{*}$ & $1,42^{*}$ & $3,11^{*}$ & 2,36 & $3,19^{*}$ & 2,79 \\
\hline
\end{tabular}

Footnote $1 .{ }^{*}$ - significantly different from the total average across the variants.

Footnote 2. $\mathrm{LSD}_{05}$ of pair comparison between the yields: $0.25 \mathrm{t} / \mathrm{ha}$.

In 2007-2008, 65 simple hybrid combinations were tested; in 2014-2015, 34 three-line hybrid combinations were tested in plots with an area of $10.15 \mathrm{~m}^{2}$ in three replications. The crop care is commonly used for the growing zone. Hybrid combinations were derived from crossing self-pollinated sunflower lines bred in the 3 institutions: sterile lines and lines - sterility fixers 
were bred in the PPI, PBGI-NCSCI and IOC; lines - pollen fertility restorers were bred in the PPI. In total, 12 sterile lines (indicated as Skh ... A (bred in the PPI) and as Od ... A (bred in the PBGI-NCSCI)), 12 lines - sterility - fixers (indicated as ZL ... B (bred in the IOC) and Od ... B (bred in the PBGI-NCSCI) and 7 lines - pollen fertility restorers (indicated as $\mathrm{Kh} \mathrm{...} \mathrm{V} \mathrm{(bred} \mathrm{in}$ the PPI) were used in crossings.

The field investigation were planned and organized, and data were statistically analyzed in accordance with the field experimentation methodology [18, 19]. A licensed data analysis and statistics add-in for MS Excel and "Statistica 6.0" licensed software were used. The response of hybrids to the growing conditions was determined by A.V. Kilchevskiy and L.V. Khotylyova's method [16]. According to this method, the response of a hybrid to cultivation conditions is characterized by its general adaptability $\left(\mathrm{V}_{i}\right)$ and the specific adaptability (SA) effects (deviation from the general adaptability in a given environment). The integral index of the genotype breeding value $\left(\mathrm{GBV}_{i}\right)$ was compared with the mean GBV in the sample under investigation.

Results and discussion. In 2007-2008, tests of 69 hybrid combinations in four sites (Kharkiv, Zaporizhzhia, Odesa, Luhansk) allowed estimating the general adaptability $\mathrm{V}_{\mathrm{i}}$ and eight values of $\mathrm{SA}_{\mathrm{ik}}$ for each of the studied combinations. According to the data presented in Table 3, the high general adaptability of a hybrid combination does not affect the effects of specific adaptability. Thus, in environment $\mathrm{Z}_{08}$ hybrid combinations with high $\mathrm{V}_{\mathrm{i}}$ had both weak (PerN $\left.\mathrm{A} / \mathrm{Kh} 785 \mathrm{~V}, \mathrm{SA}_{\mathrm{ik}}=-0.48^{*}\right)$ and strong $\left(\mathrm{Od} 4301 \mathrm{~A} / \mathrm{Kh} 785 \mathrm{~V}, \mathrm{SA}_{\mathrm{ik}}=0.45^{*}\right) \mathrm{SA}$ effects. The $\mathrm{SA}_{\mathrm{ik}}$ of hybrid combination Od $391 \mathrm{~A} / \mathrm{Kh} 720 \mathrm{~V}$ with the maximum $\mathrm{V}_{\mathrm{i}}\left(0.38^{*}\right)$ varied from -1.33 * in environment $\mathrm{O}_{07}$ to $1.28 *$ in environment $\mathrm{Kh}_{07}$.

Table 3

\section{$\mathrm{SA}_{i k}$ of the hybrid combinations that were the best in terms of $\mathrm{V}_{i}$, in the 8 testing} environments, 2007-2008.

\begin{tabular}{|c|c|c|c|c|c|c|c|c|c|c|}
\hline \multicolumn{3}{|c|}{ Hybrid combination } & \multicolumn{8}{|c|}{$S A_{i k}$} \\
\hline $\begin{array}{c}\text { Female } \\
\text { component }\end{array}$ & $\begin{array}{c}\text { Male } \\
\text { component }\end{array}$ & $\mathrm{V}_{i}$ & $\mathrm{Kh}_{07}$ & $\mathrm{Kh}_{08}$ & $\mathrm{Z}_{07}$ & $\mathrm{Z}_{08}$ & $\mathrm{~L}_{07}$ & $\mathrm{~L}_{08}$ & $\mathrm{O}_{07}$ & $\mathrm{O}_{08}$ \\
\hline Od 4301 A & Kh $785 \mathrm{~V}$ & $0.34^{*}$ & $1.60^{*}$ & $0.76^{*}$ & 0.17 & $0.45^{*}$ & $-0.42^{*}$ & $-1.01^{*}$ & $-1.61^{*}$ & 0.06 \\
\hline Od $973 \mathrm{~A}$ & $\mathrm{Kh} 720 \mathrm{~V}$ & $0.35^{*}$ & $1.88^{*}$ & $0.89^{*}$ & 0.14 & -0.23 & $-0.35^{*}$ & $-1.05^{*}$ & $-1.13^{*}$ & -0.14 \\
\hline Od $4301 \mathrm{~A}$ & $\mathrm{Kh} 720 \mathrm{~V}$ & $0.37^{*}$ & $1.75^{*}$ & $0.92^{*}$ & 0.12 & 0.11 & $-0.45^{*}$ & $-1.13^{*}$ & $-1.43^{*}$ & 0.11 \\
\hline PerN A & $\mathrm{Kh} 785 \mathrm{~V}$ & $0.37^{*}$ & $1.27^{*}$ & $0.81^{*}$ & $0.47^{*}$ & $-0.48^{*}$ & $-0.59^{*}$ & $-0.72^{*}$ & $-1.23^{*}$ & $0.47^{*}$ \\
\hline Od $391 \mathrm{~A}$ & $\mathrm{Kh} 720 \mathrm{~V}$ & $0.38^{*}$ & $1.28^{*}$ & $0.79^{*}$ & $0.41^{*}$ & -0.11 & $-0.62^{*}$ & $-0.92^{*}$ & $-1.33^{*}$ & $0.51^{*}$ \\
\hline
\end{tabular}

Footnote: * significant effects with significance level of $5 \%$

The $\mathrm{SA}_{\mathrm{ik}}$ effects estimated for environment $\mathrm{Z}_{07}$, in which the $\mathrm{t}_{\max }$ in July significantly exceeded the average $t_{\max }$ across the variants (see Table 1), is proposed as the heat resistance index of the $k^{\text {th }}$ genotype $\left(\mathrm{I}_{\mathrm{h}}\right)$. In environment $\mathrm{Z}_{07}, 10$ hybrid combinations ( $15 \%$ of the studied ones) with significantly stronger $\mathrm{SA}_{\mathrm{ik}}$ effects $\left(\mathrm{I}_{\mathrm{h}}\right)$, which varied from $0.30 *$ to $0.61^{*}$, were selected (Table 4). The yields of these hybrid combinations ranged within $2.50-3.33 *$ t/ha (the average yield $=2.49 \mathrm{t} / \mathrm{ha}$ in the experiment; the average yield $=2.51 \mathrm{t} / \mathrm{ha}$ across the environments $)$, and, according to the general adaptability $\mathrm{Vi}$, they belonged to the genotype group with a low (the average group value $\mathrm{Vi}=-0.30$ ), or medium (the average group value $\mathrm{Vi}=0.01$ ) or a high (the average group value $\mathrm{Vi}=0.29$ ) general adaptability. Five hybrid combinations combined a high general adaptability with a high heat resistance index (from $0.32 *$ to $0.50 *$ ). Hybrid combinations PerN $\mathrm{A} / \mathrm{Kh} 785 \mathrm{~V}\left(3.33^{*} \mathrm{t} / \mathrm{ha}\right)$ and $\mathrm{Od} 391 \mathrm{~A} / \mathrm{Kh} 720 \mathrm{~V}(3.27 * \mathrm{t} / \mathrm{ha})$ gave the highest yields. As to $\mathrm{GBV}_{i}$, hybrid combinations PerN A/Kh 720 V, Od 391 A/Kh 720 V, PerN A/Kh 785 V were the best in terms of yield and its stability (as compared to the average GBV of 1.25 in the experiment). However, among the genotypes selected by $\mathrm{I}_{\mathrm{h}}$, there were those that were inferior to other hybrids (ZL $52 \mathrm{~A} / \mathrm{Kh} 843 \mathrm{~V}, \mathrm{GBV}_{i}=0.75$ ) according to their breeding value.

Thus, hybrid combinations with a high heat resistance index at very high temperatures in July had low to high general adaptability, and 5 combinations ( $7.2 \%$ of the studied ones) combined a high general adaptability with a high heat resistance index. 
Table 4

Adaptability of the yields of $\mathrm{F}_{1}$ sunflower hybrids that were the best in terms of $\mathrm{SA}_{i k}$ in environment $\mathbf{Z}_{07}$

\begin{tabular}{|c|c|c|c|c|c|}
\hline Hybric & bination & & & & \\
\hline $\begin{array}{l}\text { Female compo- } \\
\text { nent }\end{array}$ & Male component & $\begin{array}{c}\mathrm{SA}_{i k} \\
\left(\mathrm{I}_{h}\right)\end{array}$ & Yield, t/ha, $Z_{07}$ & $\mathrm{~V}_{i}$ & $\mathrm{GBV}_{i}$ \\
\hline ZL $42 \mathrm{~A}$ & Kh $785 \mathrm{~V}$ & $0.30^{*}$ & 2.64 & $-0.15^{*}$ & 1,15 \\
\hline ZL 48 A & Kh $843 \mathrm{~V}$ & $0.31^{*}$ & 2.50 & $-0.30^{*}$ & 0,97 \\
\hline PerN A & $\mathrm{Kh} 720 \mathrm{~V}$ & $0.32^{*}$ & $3.03^{*}$ & $0.22^{*}$ & 1,32 \\
\hline $\mathrm{ZL} 42 \mathrm{~A}$ & $\mathrm{Kh} 720 \mathrm{~V}$ & $0.36^{*}$ & $3.04^{*}$ & $0.19^{*}$ & 1,21 \\
\hline Od $391 \mathrm{~A}$ & $\mathrm{Kh} 720 \mathrm{~V}$ & $0.41^{*}$ & $3.27^{*}$ & $0.38^{*}$ & 1,62 \\
\hline PerN A & Kh $843 \mathrm{~V}$ & $0.45^{*}$ & 2.75 & $-0.19^{*}$ & 0,99 \\
\hline PerN A & $\mathrm{Kh} 785 \mathrm{~V}$ & $0.47^{*}$ & $3.33^{*}$ & $0.37^{*}$ & 1,65 \\
\hline Od 395 A & $\mathrm{Kh} 720 \mathrm{~V}$ & $0.50^{*}$ & $3.17^{*}$ & $0.13^{*}$ & 1,02 \\
\hline ZL $52 \mathrm{~A}$ & Kh $843 \mathrm{~V}$ & $0.52^{*}$ & 2.82 & $-0.34^{*}$ & 0,75 \\
\hline Odol $1 \mathrm{~A}$ & Kh $843 \mathrm{~V}$ & $0.61^{*}$ & $3.01^{*}$ & -0.10 & 1,06 \\
\hline $\mathrm{LSD}_{05}$ for pair co & ison & 0.38 & 0.40 & 0.14 & - \\
\hline
\end{tabular}

Footnote: ${ }^{*}$ - significant differences with significance level of $5 \%$

In 2014-2015, tests of 34 three-line hybrid combinations in four sites (Kharkiv, Zaporizhzhia, Odesa, Sumy) allowed estimating the general adaptability Vi and eight values of $\mathrm{SA}_{\mathrm{ik}}$ for each combination under investigation. We propose the $\mathrm{SA}_{\mathrm{ik}}$ computed for environment $\mathrm{Z}_{14}$, in which the $t_{\max }$ of the first 10 days of August significantly exceeded the average $t_{\max }$ across the variants (see Table 2), as the heat resistance index of the $k^{\text {th }}$ genotype $\left(\mathrm{I}_{\mathrm{h}}\right)$. The best 10 genotypes were distinguished after ranking the hybrids by $\mathrm{I}_{\mathrm{h}}$ (Table 5).

Table 5

Adaptability of the yields of three-line sunflower hybrids, that were the best in terms of $\mathrm{SA}_{i k}$ in environment $\mathrm{Z}_{14}$

\begin{tabular}{lcccrc}
\hline \multicolumn{2}{c}{ Hybrid combination } & $\begin{array}{c}\mathrm{SA}_{i k} \\
\left(\mathrm{I}_{h}\right)\end{array}$ & Yield, t/ha, $\mathrm{Z}_{14}$ & $\mathrm{~V}_{i}$ & $\mathrm{GBV}_{i}$ \\
\hline Female component & Male component & -0.68 & $2.12^{*}$ & 0.02 & 1,41 \\
Od 1002 A / Od 1050 B & -0.68 & $2.05^{*}$ & -0.07 & 1,59 \\
Od 1050 A / ZL 40 B & -0.67 & $2.00^{*}$ & $-0.43^{*}$ & 1,53 \\
Skh 51 A / Od 391 B & & -0.65 & $2.24^{*}$ & $0.31^{*}$ & 1,57 \\
Skh 1006 A / Od 973 B & Kh 06134 V & -0.64 & $2.33^{*}$ & $-0.21^{*}$ & 1,71 \\
Skh 51 A / ZL 50 B & & -0.64 & $2.20^{*}$ & $0.41^{*}$ & 1,34 \\
Skh 1002 A / ZL 50 B & & -0.63 & $2.35^{*}$ & $-0.21^{*}$ & 1,75 \\
Mkh 524 A / ZL 50 B & -0.62 & $2.01^{*}$ & 0.14 & 1,32 \\
Od 529 A / ZL 42 B & -0.60 & $2.19^{*}$ & -0.04 & 1,49 \\
Od 973 A / ZL 10 B & -0.46 & $2.07^{*}$ & 0.03 & 1,37 \\
LSD 05 for pair comparison & 0,34 & 0.17 & 0.12 & - \\
\hline
\end{tabular}

Footnote: * - significant differences with significance level of $5 \%$

The $I_{h}$ of these combinations varied from -0.46 to -0.68 , with the average of -0.83 in the environment. In terms of the general adaptability $\mathrm{Vi}$, these hybrid combinations belonged to a group of genotypes with a low (the average group value $\mathrm{Vi}=-0.22$ ), or medium (the average group value $\mathrm{Vi}=0.00$ ), or a high (the average group $\mathrm{Vi}=0.21$ ) general adaptability. Two hybrid combinations (5.9\% of the investigated ones) coupled a high general adaptability with a high heat resistance index: Skh 51 A / Od 391 B // Kh 06134 V and Skh 51 A / ZL 50 B // Kh 06134 V. Their yields varied from $2.00^{*}$ to $2.35^{*} \mathrm{t} / \mathrm{ha}$ (the average $=2.79 \mathrm{t} / \mathrm{ha}$ in the experiment; the aver- 
age $=1.96 \mathrm{t} / \mathrm{ha}$ in the environment); therefore, it was significantly lower compared to the average in the experiment, but exceeded the average in the environment. The highest yields were obtained from hybrid combinations Skh 1002 A / ZL 50 B // Kh 06134 V (2.35* t/ha) and Skh 1006 A / Od $973 \mathrm{~B} / / \mathrm{Kh} 06135 \mathrm{~V}\left(2.3^{*} \mathrm{t} / \mathrm{ha}\right)$. The same hybrid combinations were the best in terms of yield and its stability (according to their $\mathrm{GBV}_{i}$ compared with the average GBV of 1.40 in the experiment). However, among the genotypes selected by $\mathrm{I}_{\mathrm{h}}$, there were those that were inferior to other hybrids by breeding value $\left(\mathrm{GBV}_{i}=1.32\right.$ for combination Mkh $524 \mathrm{~A} / \mathrm{ZL} 50 \mathrm{~B} / / \mathrm{Kh}$ $06134 \mathrm{~V} ; \mathrm{GBV}_{i}=1.34$ for combination Skh 51 A / ZL 50 B // Kh 06134 V).

Thus, at high temperatures of the first 10 days of August, two hybrid combinations $(5.9 \%$ of the studied ones) coupled a high general adaptability with the highest heat resistance index of the studied combinations.

Line - pollen fertility restorer $\mathrm{Kh} 06134 \mathrm{~V}$, which is resistant to downy mildew race 730 , with a high combining ability for the seed yield and other useful features, was the male component of the best three-line hybrids [20].

Conclusions. Basing on dependence of the sunflower yield on the temperature regime during the growing season, we proposed the heat resistance index of a genotype in the field conditions, which is defined as the specific adaptability $\left(\mathrm{SA}_{\mathrm{ik}}\right)$ effect calculated for each hybrid in an environment with a high temperature, i.e., the average maximum air temperature for a certain period.

In 2007 with the $t_{\max }$ of $34.3^{\circ} \mathrm{C}$ in July, in the IOC's experimental field, 5 hybrid combinations (7.2\% of the studied ones) were selected. They combined a high general adaptability with a high heat resistance index (from $0.32 *$ to $0.50^{*}$ ). In 2014 with the $\mathrm{t}_{\max }$ of $34.6^{\circ} \mathrm{C}$ in the first 10 days of August, in the IOC's experimental field, 2 hybrid combinations $(5.9 \%$ of the studied ones), which combined a high general adaptability with the highest heat resistance index of the combinations under investigation (from -0.64 to -0.65 ), were detected.

The heat resistance index is suitable for selection of accessions that, in a certain group of genotypes, at very high temperatures, are able to maintain stable yields, or reduce them less than other genotypes.

\section{Список використаних джерел}

1. Божко Л.Ю. Оцінка впливу екстремальних явищ на продуктивність сільськогосподарських культур: навчальний посібник / МОН України; Одес. держ. еколог. ун-т. Одеса: Екологія, 2013. 240 с.

2. Клімат України ; за ред. В.М. Ліпінського, В.А. Дячука, В.М. Бабіченко. Київ: Мін-во екології та природних ресурсів України, НАН України. Видавництво Раєвського, 2003. $344 \mathrm{c}$.

3. Singh B.D. Textbook of plant breeding. New Delhi: Kalyani Publihers. 2004. P. 123-125.

4. Chimenti C., Hall A., Lopez M. Embryo-growth rate and duration in sunflower as affected by temperature. Field Crops Research. 2001. Vol. 69. № 1. P. 81-88.

5. Gonzalez J., Mancuso N., Luduena P. Sunflower yield and climatic variables. Helia. 2013. Vol. 36. № 58. P. 69-76.

6. Kalyar T. et. Al. Handling sunflower (Helianthus annuus L.) populations under heat stress. Archives of Agronomy and Soil Science. 2014. Vol. 60, No. 5. P. 655-672.

7. Макляк К.М., Кириченко В.В. Реакция гибридов подсолнечника разных групп спелости на температурный режим периода их вегетации. Масличные культуры. 2016. Вып. 4 (168). C. 55-60.

8. Miller B.C. et al. Effect of planting date and plant population on sunflower performance. Agron. J. 1984. Vol. 76. № 4. P. 511-515.

9. Кириченко В.В., Макляк К.М., Вареник Б. Ф. та ін. Екологічне випробування гібридів соняшнику селекційними установами системи Національної академії аграрних наук України. НТБ ІОК. Запоріжжя, 2010. Вип. 15. С. 49-56. 
10. Кириченко В.В., Макляк К.М., Кутіщева Н.М., Скворцов І.В. Урахування параметрів екологічного середовища в рамках прискорення трансферу селекційних інновацій соняшнику. Вісник ЦНЗ АПВ Харківської області. 2010. Вип. 7. С. 57-68.

11. Кириченко В.В., Макляк К.М., Кутіщева Н.М., Вареник Б.Ф. Параметри екологічного середовища як фону для оцінки врожайності гібридів соняшнику. Фактори експериментальної еволюції організмів. 2010. Т. 8. С. 354-359.

12. Oka H.I. Breeding for wide adaptability. Adaptability in plants: use and management of biological resources. Breeding for wide adaptability. Adaptability in plants: use and management of biological resources. Tokyo, 1975. Vol. 2. P. 117-185.

13. Фурсова А.К. Биология семяобразования подсолнечника. Харьков: Харьк. гос. аграр. ун-т., 1993. 199 с.

14. Chimenti C.A., Hall A.J. Grain number responses to temperature during floret differentiation in sunflower. Field Crops Res. 2001. Vol. 72. P. 177-184.

15. Chimenti C., Hall A., Lopez M. Embryo-growth rate and duration in sunflower as affected by temperature. Field Crops Research. 2001. Vol. 69. № 1. P. 81-88.

16. Кильчевский А.В., Хотылева Л.В. Экологическая селекция растений. Минск: Тэхналогия, 1997. 372 с.

17. Національний атлас України : карти; голов. ред. Л.Г. Руденко. Київ: Нац. акад. наук України, 2008. 439 с.

18. Доспехов Б.А. Методика полевого опыта. Москва: Агропромиздат, 1985. $351 \mathrm{c}$.

19. Вольф В.Г. Статистическая обработка опытных данных. Москва: Колос, 1966. 256 с.

20. Кильчевский А.В., Хотылева Л.В. Экологическая селекция растений. Минск : Тэхналогия, 1997. 372 с.

21. Каталог ліній-відновників фертильності пилку соняшнику (Helianthus annuus L.); підгот.: В.В. Кириченко, В.І. Сивенко, О.А. Сивенко... К.М. Макляк та ін. Харків: НААН, ІР ім. В.Я. Юр'єва, 2015. 33 с.

\section{References}

1. Bozhko LYu. Estimation of the impact of extreme events on the crop performance: guide / Ministry of Education and Science of Ukraine; Odesa State Ecological University. Odesa: Ekolohiia, 2013. 240 p.

2. Climate of Ukraine; ed. by VM Lipinskyi, VA Diachuk, VM Babichenko. Ministry of Ecology and Natural Resources of Ukraine, National Academy of Sciences of Ukraine. Kyiv: Raievskyi's Publishing House, 2003. 344 p.

3. Singh BD. Textbook of plant breeding. New Delhi: Kalyani Publihers, 2004. P. 123-125.

4. Chimenti C, Hall A, Lopez M. Embryo-growth rate and duration in sunflower as affected by temperature. Field Crops Research. 2001; 69(1): 81-88.

5. Gonzalez J, Mancuso N, Luduena P. Sunflower yield and climatic variables. Helia. 2013; 36(58): 69-76.

6. Kalyar T et. al. Handling sunflower (Helianthus annuus L.) populations under heat stress. Archives of Agronomy and Soil Science. 2014; 60(5): 655-672.

7. Maklyak KM, Kyrychenko VV. Response of sunflower hybrids belonging to various ripeness groups to the temperature regime during their vegetation period. Maslichnyye Kultury. 2016; 4(168): 55-60.

8. Miller BC et al. Effect of planting date and plant population on sunflower performance. Agron. J. 1984; 76(4): 511-515.

9. Kyrychenko VV, Makliak KM, Varenyk BF et al. Environmental trials of sunflower hybrids by breeding institutions of the National Academy of Agrarian Sciences of Ukraine. NTB IOK. 2010; 15: 49-56.

10. Kyrychenko VV, Makliak KM, Kutishcheva NM, Skvortsov IV. Account for parameters of an ecological environment as part of acceleration of transfer of sunflower breeding innovations. Visnyk TsNZ APV Kharkivskoi Oblasti. 2010; 7: 57-68. 
11. Kyrychenko VV, Makliak KM, Kutishcheva NM, Varenyk BF. Parameters of an ecological environment as a background for assessing the yield capacity of sunflower hybrids. Factors of Experimental Evolution of Organisms. 2010; 8: 354-359.

12. Oka HI. Breeding for wide adaptability. In: Adaptability in plants: use and management of biological resources. Breeding for wide adaptability. Adaptability in plants: use and management of biological resources. Tokyo, 1975. Vol. 2. P. 117-185.

13. Fursova AK. Biology of sunflower seed formation. Kharkiv: Kharkiv State Agrarian University, 1993. 199 p.

14. Chimenti CA, Hall AJ. Grain number responses to temperature during floret differentiation in sunflower. Field Crops Res. 2001; 72: 177-184.

15. Chimenti C, Hall A, Lopez M. Embryo-growth rate and duration in sunflower as affected by temperature. Field Crops Research. 2001; 69(1): 81-88.

16. Kilchevskiy AV, Khotylyova LV. Environmental breeding of plants. Minsk: Tekhnologiya, 1997. $372 \mathrm{p}$.

17. National atlas of Ukraine: maps. In: LH Rudenko, chief editor. Kyiv: National Academy of Sciences of Ukraine, 2008. 439 p.

18. Dospekhov BA. Methods of field experimentation. Moscow: Agropromizdat, 1985. $351 \mathrm{p}$.

19. Wolf VG. Statistical processing of experimental data. Moscow: Kolos, 1966. 256 p.

20. Catalog of sunflower (Helianthus annuus L.) lines - pollen fertility restorers. In: prepared by VV Kyrychenko, VI Syvenko, OA Syvenko, KM Makliak et al. Kharkiv: NAAS, PPI nd.a. VYa Yuriev, 2015. 33 p.

\section{ОЦІНКА ГІБРИДІВ СОНЯШНИКУ ЗА МІНЛИВІСТЮ ВРОЖАЙНОСТІ В УМОВАХ ДУЖЕ ВИСОКИХ ТЕМПЕРАТУР ПОВІТРЯ}

${ }^{1}$ Макляк К.М., ${ }^{1}$ Кириченко В.В., ${ }^{2}$ Вареник Б.Ф., ${ }^{3}$ Кутіщева Н.М., ${ }^{4}$ Троценко В.І.

1 - Інститут рослинництва ім. В.Я. Юр'єва НААН, Україна;

2 - Селекційно-генетичний інститут-Національний центр насіннєзнавства і сортовивчення, Україна;

3 - Інститут олійних культур НААН, Україна;

4 - Інститут сільського господарства Північного Сходу НААН, Україна

Мета і задачі дослідження. Ціль дослідження - розробити методичні підходи до кількісної оцінки мінливості врожайності гібридів соняшнику в умовах дуже високої температури повітря (жари).

Матеріал і методика. Польові дослідження проведено в умовах помірно посушливої зони та зони недостатнього зволоження України, в п'яти географічних пунктах. Випробувано 99 простих і трилінійних гібридних комбінацій. Реакцію гібридів на умови вирощування оцінювали за показниками загальної та специфічної адаптивної здатності.

Обговорення результатів. Доведено можливість диференціації гібридів за ефектами специфічної комбінаційної здатності, значення яких у середовищах с дуже високими температурами впродовж чутливих етапів розвитку соняшнику прийнято за показник «індекс жаростійкості генотипу» $\left(\mathrm{I}_{ж}\right)$. В умовах дуже високих температур липня виділено гібридів комбінації з достовірно високими Іж. П'ять гібридних комбінацій (7,2% від до-

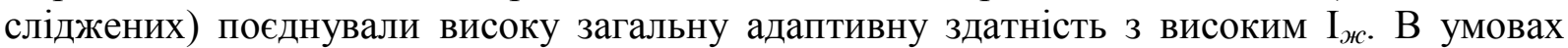
дуже високих температур першої декади серпня виділено дві гібридні комбінації (5,9 \% від досліджених)

3 високою загальною адаптивною здатністю та високим $\mathrm{I}_{ж}$.

Висновки. Показник «індекс жаростійкості» придатний для виділення зразків, які в певній групі генотипів в умовах дуже високих температур повітря здатні зберігати врожайність на стабільному рівні, або зменшувати іiї у меншому ступені, ніж інші генотипи.

Ключові слова: соняшник, випробування, адаптивна здатність, загальна, специффічна, індекс, жаростійкість 
${ }^{1}$ Макляк Е.Н., ${ }^{1}$ Кириченко В.В. ${ }^{2}$ Вареник Б.Ф., ${ }^{3}$ Кутищева Н.Н., ${ }^{4}$ Троценко В.И.

1 - Институт растениеводства им. В.Я. Юрьева НААН, Украина

2 - Селекционно-генетический институт-Национальный центр семеноведения и сортоизучения, Украина

3 - Институт масличных культур НААН, Украина

${ }^{4}$ - Институт сельского хозяйства Северного Востока НААН, Украина

Цели и задачи исследования. Цель исследования - разработать методические подходы к количественной оценке изменчивости урожайности гибридов подсолнечника в условиях очень высокой температуры воздуха (жары).

Материал и методика. Полевые исследования проведены в условиях умеренно засушливой зоны и зоны недостаточного увлажнения Украины, в пяти географических пунктах. Испытаны 99 простых и трехлинейных гибридных комбинаций. Реакцию гибридов на условиях выращивания оценивали за показателями общей и специфической адаптивной способности.

Обсуждение результатов. Доказана возможность дифференциации гибридов по эффектам специфической комбинационной способности, значения которых в средах с очень высокими температурами на протяжении чувствительных этапов развития подсолнечника приняты за показатель «индекс жаростойкости генотипа» $\left(И_{ж}\right)$. В условиях очень высоких температур июля выделены гибридные комбинации с достоверно высокими $И_{ж}$. Пять гибридных комбинаций (7,2 \% от испытанных) объединяли высокую общую адаптивную способность с высоким Иж. В условиях очень высоких температур первой декады августа выделены две гибридные комбинации (5,9 \% от испытанных) с высокой общей адаптивной способностью и высокими Иж.

Выводы. Показатель «индекс жаростойкости» пригодный для выделения образцов, которые в определенной группе генотипов в условиях очень высоких температур воздуха способны сохранять урожайность на стабильном уровне, или уменьшать ее в меньшей степени, чем другие генотипы.

Ключевые слова: подсолнечник, испытание, адаптивная способность, общая, специфическая, индекс, жаростойкость

\section{EVALUATION OF SUNFLOWER HYBRIDS FOR YIELD VARIABILITY AT VERY HIGH AIR TEMPERATURES}

${ }^{1}$ Makliak K.M., ${ }^{1}$ Kyrychenko V.V., ${ }^{2}$ Varenyk B.F., ${ }^{3}$ Kutishcheva N.M., ${ }^{4}$ Trotsenko V.I.

${ }^{1}$ - Plant Production Institute named after V.Ya. Yuriev of NAAS, Ukraine;

2 - Plant Breeding and Genetic Institute - National Center of Seed and Cultivar Investigation,

Ukraine;

${ }^{3}$ - Institute of Oil Crops of NAAS, Ukraine;

${ }^{4}$ - Institute of Agriculture of the North-East of NAAS, Ukraine

Purpose and objective. The purpose of the study was to develop methodological approaches to quantification of the yield variability of sunflower hybrids at very high air temperatures (heat).

Materials and methods. The field investigations were conducted in the moderately arid zone and the insufficiently humidified zone of Ukraine, in five geographical locations. Ninety nine simple and three-line hybrid combinations were tested. The response of the hybrids to the growing conditions was evaluated by general and specific adaptability measures.

Results and discussion. The possibility of differentiation of hybrids according to the specific combining ability effects was proved. The effect values in environments with very high tem- 
peratures during the susceptible stages of sunflower development were taken as the heat resistance indices of genotypes $\left(\mathrm{I}_{\mathrm{h}}\right)$. At very high temperatures in July, hybrid combinations with significantly high $\mathrm{I}_{\mathrm{h}}$ were detected. Five hybrid combinations (7.2\% of the studied ones) combined a high general adaptability with a high $\mathrm{I}_{\mathrm{h}}$. At very high temperatures during the first 10 days of August, two hybrid combinations (5.9\% of the studied ones) with a high general adaptability and a high $\mathrm{I}_{\mathrm{h}}$ were singled out.

Conclusions. The heat resistance index is suitable for detecting accessions that, in a certain group of genotypes, at very high air temperatures, are able to maintain stable yields, or reduce them less than other genotypes.

Key words: sunflower, trials, adaptability, general, specific, index, heat resistance

УДК 635.655:631.527:581.19

DOI:10.30835/2413-7510.2018.152139

\section{ОСОБЛИВОСТІ ФОРМУВАННЯ БІОХІМІЧНОГО СКЛАДУ НАСІННЯ СУЧАСНИХ СOPTIB CÖ̈}

Рябуха С.С., Чернишенко П.В., Сєрікова Л.Г., Святченко С.І. Інститут рослинництва ім. В.Я. Юр'єва НААН, Україна

Установлено значну диференціацію сортів сої за показниками врожайності та якості насіння. Виділено сорти 3 максимальним проявом ознак: урожайності - сорт Красуня (1,6 т/га), вмісту білка в насінні - сорт Райдуга (38,1 \%), вмісту олії та інтенсивності іiі утворення - сорт Спритна (18,2 \% та 2,969 кг/га/добу відповідно), сумарного вмісту білка та олії, інтенсивності утворення білка, інтенсивності утворення білка та олії - сорт Перлина (55,6 \%; 6,265 кг/га за добу; 9,176 кг/га за добу відповідно). Показано, що сорти ранньостиглої групи мають здатність до утворення білка та олії в насінні на рівні та вище, ніж сорти середньоранньої та середньостиглої груп.

Ключові слова: соя, сорт, урожайність, насіння, вміст, білок, олія, інтенсивність утворення

Вступ. Ріст народонаселення Землі і невідкладна необхідність забезпечення його продуктами харчування вимагає випереджаючого росту виробництва продовольчих ресурсів, зокрема білково-олійної сировини. Їх поповнення значною мірою забезпечується за рахунок сої, яка являє собою основу світової піраміди рослинного білка і олії, важливу складову продовольства $[1,2]$, забезпечуючи близько 20 \% світових білкових ресурсів $[3,4]$.

Аналіз літературних джерел, постановка проблеми. Соя багата на повноцінний білок, поліненасичені ліпіди, харчові волокна, вітаміни, макро- та мікроелементи, що привертає увагу вчених і виробників для створення функціональних і лікувальних продуктів харчування $[1,2,4]$.

Рослинний білок $є$ найважливішою складовою частиною харчових і кормових ресурсів, використання яких суттєво впливає на стан здоров'я людей, тривалість і рівень життя. Наприкінці XX сторіччя у загальному балансі білка частка рослинного складала 70 \%, а 30 \% припадало на тваринний [5].

Завдяки здатності накопичувати в насінні понад 40 \% високоякісного білка соя стала однією з головних культур світового землеробства $[1,2,3,4,6]$. Створюються спеціалізовані сорти сої харчового використання, спостерігається тенденція до збільшення вмісту білка в насінні нових сортів сої. В Кореї та КНР - країнах первинного центру походження

() С.С. Рябуха, П.В. Чернишенко, Л.Г. Сєрікова, С.І. Святченко. 2018.

ISSN 1026-9959. Селекція і насінництво. 2018. Випуск 114. 